\title{
Genomics and proteomics in liver fibrosis and cirrhosis
}

\author{
Rebekka A Hannivoort ${ }^{1,2}$, Virginia Hernandez-Gea ${ }^{1}$ and Scott L Friedman ${ }^{1 *}$
}

\begin{abstract}
Genomics and proteomics have become increasingly important in biomedical science in the past decade, as they provide an opportunity for hypothesis-free experiments that can yield major insights not previously foreseen when scientific and clinical questions are based only on hypothesis-driven approaches. Use of these tools, therefore, opens new avenues for uncovering physiological and pathological pathways. Liver fibrosis is a complex disease provoked by a range of chronic injuries to the liver, among which are viral hepatitis, (non-) alcoholic steatohepatitis and autoimmune disorders. Some chronic liver patients will never develop fibrosis or cirrhosis, whereas others rapidly progress towards cirrhosis in a few years. This variety can be caused by disease-related factors (for example, viral genotype) or host-factors (genetic/epigenetic). It is vital to establish accurate tools to identify those patients at highest risk for disease severity or progression in order to determine who are in need of immediate therapies. Moreover, there is an urgent imperative to identify non-invasive markers that can accurately distinguish mild and intermediate stages of fibrosis. Ideally, biomarkers can be used to predict disease progression and treatment response, but these studies will take many years due to the requirement for lengthy follow-up periods to assess outcomes. Current genomic and proteomic research provides many candidate biomarkers, but independent validation of these biomarkers is lacking, and reproducibility is still a key concern. Thus, great opportunities and challenges lie ahead in the field of genomics and proteomics, which, if successful, could transform the diagnosis and treatment of chronic fibrosing liver diseases.
\end{abstract}

Keywords: cirrhosis, genomics, liver fibrosis, mass spectrometry, microarray, proteomics

\section{Introduction}

Liver fibrosis results from a wound-healing response to chronic injury, which leads to excessive matrix, or scar deposition. This scar tissue can restrict blood flow due to contraction of the organ, leading to progressive liver damage and cirrhosis (the end stage of fibrosis), complicated by liver failure, portal hypertension and/or hepatocellular carcinoma [1]. Fibrosis is prominent in chronic liver diseases, including viral hepatitis, alcoholic and non-alcoholic steatohepatitis, toxic liver injury, autoimmune diseases and several genetic diseases. There have been two major priorities for therapy to reduce fibrosis: 1) to establish treatments for the diseases that lead to liver fibrosis; and, 2) to identify agents that

\footnotetext{
* Correspondence: scott.friedman@mssm.edu

${ }^{1}$ Department of Medicine/Division of Liver Diseases, Mount Sinai School of Medicine, New York, NY 10029, USA

Full list of author information is available at the end of the article
}

directly slow or reverse fibrogenesis independent of the underlying disease.

A key discovery in understanding fibrosis has been the role of hepatic stellate cells (HSCs), vitamin A storing cells in the space of Disse, which, when activated, transform into myofibroblast-like cells, shedding their vitamin A content, and producing fibrogenic proteins, including collagens and tissue inhibitor of metalloproteinases-1 (TIMP-1) [2]. This review will focus on the contribution of high-throughput genomic and proteomic approaches to the study of fibrogenesis and fibrosis progression, concentrating on the most prevalent human chronic liver diseases and findings from animal models in liver tissue, isolated liver cells, cell lines and serum.

The role of genomics and proteomics in degenerative diseases and liver fibrosis

Genetic diseases can be classified as chromosomal abnormalities (for example, trisomy 21), Mendelian

\section{Biomed Central}

(c) 2012 Hannivoort et al; licensee BioMed Central Ltd. This is an Open Access article distributed under the terms of the Creative Commons Attribution License (http://creativecommons.org/licenses/by/2.0), which permits unrestricted use, distribution, and reproduction in any medium, provided the original work is properly cited. 
disorders (single gene alterations with typical inheritance patterns, like autosomal dominant/recessive or Xlinked), and complex diseases that are influenced by many genetic and environmental components. Degenerative diseases like liver fibrosis are complex illnesses [3]. The genetic contributions to these disorders are not attributable to a single gene alteration, but rather to a host of genetic susceptibilities defined by single nucleotide polymorphisms (SNPs) that predispose an individual to a disease. The susceptibility to an accumulation of environmental influences is either enhanced or reduced by genetic factors, thereby defining an individual's disease risk. Studies investigating these genetic traits are complicated, because there are many genes that influence the risk for complex diseases, yet the impact of each single genetic variant by itself is small. Therefore, large numbers of subjects are needed to provide sufficient statistical power to yield robust conclusions. Currently, there are almost 13 million SNPs catalogued in the NCBI human SNP database. Approaches to identify SNPs that are linked with a specific disease range from efforts to sequence specific disease-causing genes to genome scans requiring sequencing of large numbers of known SNPs that may or may not be associated with the disease.

Genomic and proteomic screening methods are often used to identify classes of genes that are differentially expressed in disease. These classes provide the investigator with potential pathways that could be involved in the regulation of this disease, thereby narrowing the focus of subsequent studies to uncover disease mechanisms and potential targets for therapy. By not limiting the study to pathways already associated with a disease, many new pathways not previously implicated are now under investigation [4].

This prospect is especially compelling in degenerative diseases like liver fibrosis, as these conditions often develop slowly, and therapies may not be necessary for all subclasses of patients [5]. Regardless of the etiology of liver fibrosis, some people progress rapidly towards cirrhosis, whereas others never develop fibrosis in the first place, or have slow progression of their fibrosis. It seems very unlikely that this phenomenon can be attributed solely to environmental influences. Identifying which patients are unlikely to ever progress to cirrhosis may prevent overtreatment of many patients.

Another use for these screening methods is to identify expression profiles, or patterns of expression of many genes, that in aggregate correspond with disease outcome or the response to therapy. By analyzing these different gene/proteome classes, investigators may ultimately predict an individual patient's response to therapy more accurately, or identify those who are at greatest risk of progression, thereby refining treatment decisions.

\section{The need for non-invasive markers in the assessment of fibrosis progression}

The need to assess hepatic fibrosis progression is becoming more important as the incidence of advanced liver disease continues to rise, especially due to viral hepatitis and fatty liver disease. Liver biopsies are currently the 'gold standard' for determining the presence and progression of liver fibrosis. They are performed percutaneously, via transjugular access, or during abdominal surgery. Liver biopsies have a low complication rate; however, significant hemorrhage may rarely occur, requiring hospitalization in approximately $2 \%$ of the patients; moreover, some patients have contraindications for liver biopsy [6-8]. Additionally, analysis of liver biopsy is often undermined by sampling error and inter-observer variation [ [6,9-15]. Studying mRNA and protein disease profiles in liver biopsies is challenging, as tissue sample sizes are small, especially for protein analysis, and the biopsies contain a mix of many different cell types, including hepatocytes, hepatic stellate cells, Kupffer cells, endothelial cells, lymphocytes, red blood cells and bile duct epithelial cells. To study a single cell population from tissue sections requires laser-capture micro-dissection, which yields even less mRNA and protein than biopsy [15].

Close follow-up of liver disease by serial biopsy is not practical due to its invasive nature, fueling the need to find alternatives for liver biopsy. A less invasive and more accurate diagnostic tool would aid in diagnosis of fibrosis, follow-up of established therapies and evaluation of experimental therapies. Moreover, hepatocellular carcinoma ( $\mathrm{HCC})$ is one of the main complications of cirrhosis, and early detection markers that distinguish HCC from cirrhosis could significantly reduce morbidity and mortality. In the past ten years, genomic, transcriptomic and proteomic studies have provided candidate biomarkers for fibrosis assessment. Thus, in combination with standard laboratory serum analysis, these have led to novel fibrosis assessment tools using indirect and direct fibrosis markers, like FibroSpect (Prometheus Laboratories; San Diego, CA, US), FibroTest (BioPredictive;Paris, FR) and Fibroscan (Echosens; Paris, FR), ActiTest (BioPredictive;Paris, FR) and APRI (public domain) [16-20]. For a more exhaustive overview of currently used serum biomarkers, see a recent review by Smith et al. [21].

These fibrosis assessment tests have shown promising results, but a number of pitfalls are encountered, including limited availability, inter-laboratory variation, cost, insufficient resolution to differentiate between intermediate stages of fibrosis and false positive results due to other conditions, such as increased venous pressure or steatosis [22-29].

Because current methods for non-invasive assessment of liver fibrosis lack resolution, particularly in the 
intermediate fibrosis stages, more research is being directed towards genomics and proteomics in the search of biomarkers that provide a close association with fibrosis stage [30-35].

\section{Technical aspects of genomics and proteomics in chronic liver disease \\ Genomics and transcriptomics}

Genomics comprises the study of the genetic information (DNA, or RNA in certain viruses) of an organism. Transcriptomics aims to elucidate the transcripts of the genome or gene expression levels on the RNA level under varying conditions as changes in mRNA expression do not necessarily correspond with changes in protein expression, since alternative splicing, protein production, degradation and post-translational modifications influence protein stability and function $[36,37]$.

The cDNA microarray is the most frequently used high-throughput screening method for gene expression profiling. These 'lab-on-a-chip' assays contain specified DNA oligonucleotide probes in spots on a chip that hybridize with oligonucleotides from tissue or cells providing a quantitative assessment of the transcribed genes [42-44]. Thousands of genes can be analyzed simultaneously with cDNA microarray and variants on this technique include specialized arrays that can detect SNPs and alternative splice variants (exon junction arrays) [38-41].

Serial analysis of gene expression (SAGE) analyzes the transcriptome by cloning strings of short cDNA fragments into bacteria, sequencing the cDNA fragments and then counting the number of cDNA fragments. This technique can yield information on both gene expression and alternative splicing and can help identify previously unknown genes [42,43].

Target genes that are revealed by the genomics/transcriptomics screens are generally validated by reverse transcription quantitative polymerase chain reaction (RT-qPCR), which is more quantitative and more reproducible than microarray, requires less mRNA and is more sensitive for genes that are expressed at low levels.

\section{Proteomics}

Proteomics is the study of the proteome in a cell compartment, tissue or organism comprising all proteins that are encoded for in the genome. Mass spectrometry (MS) is the key technique in proteomics. Many variants of mass spectrometers are currently in use, but they all rely on the same concept: to determine the accurate mass of a protein by measuring the mass-to-charge $(\mathrm{m} /$ $z$ ) ratio. In short, mass spectrometers consist of an ion source, a mass analyzer and a mass detector. After ionization, proteins and peptides travel through the mass analyzer, which evaluates their ratio of charge $(z)$ versus mass $(m)$. The mass detector counts the number of molecules per charge-to-mass ratio, and can provide the user with an output as a mass spectrum, with the $m / z$ ratio on the $x$-axis and the molecule count per $m / z$ on the $y$-axis [44].

MS is preceded by a separation step of proteins, either through 2D-polyacrylamide gel electrophoresis (2-DE/ 2D-PAGE), liquid chromatography (LC) or gel electrophoresis (DIGE) [45-47]. Once the protein spots are excised from the gel and digested, they can be processed through one mass analyzer (MS) to identify peptide mass, or two mass analyzers (MS/MS) to determine amino acid sequence.

MS requires ionization of proteins and peptides and two soft-ionizing techniques have been developed: matrix-assisted laser desorption/ionization (MALDI) and Electrospray ionization (ESI). Both techniques charge molecules that are subsequently analyzed by one or two mass analyzers (MS or versus tandem MS/MS). Timeof-flight (TOF) mass analyzers deduct peptide mass by measuring the time it takes for a charged peptide to travel through a vacuum tube in an electric field and can also be combined with one (Q-TOF) or two quadrupoles (Q-Q-TOF), which uses an oscillating electric field to selectively allow for molecules with a specific range of $\mathrm{m} / \mathrm{z}$ ratios to proceed without collision [48].

When extremely high resolution is required, Fourier transform-ion cyclotron resonance (FT-ICR) MS or orbitrap can be used. The charged molecules are injected into a Penning ion trap where detectors measure the signal of molecules that pass. The $\mathrm{m} / \mathrm{z}$ ratio determines the frequency with which the ion passes over the detector [49-51].

Surface-enhanced laser desorption/ionization (SELDI) analyzes protein mixtures that selectively bind to a biochip with the characteristics of choice. It needs only a small amount of crude sample (for example, serum or small liver biopsies), and is suitable for profiling multiple low-molecular-weight proteins. SELDI does not provide direct identification of the proteins. However, the peak profiles generated by SELDI can be useful by themselves in diagnostics, or in predicting prognosis and/or treatment response. Since manual labor is minimal, SELDI is by itself a suitable technique for highthroughput screening, especially for serum biomarkers; however, the cost is still too high for application on a large clinical scale [52-54]. For an excellent overview of the different types of mass spectrometers and their individual strengths and weaknesses, see a review by Domon and Aebersold [55].

A different type of high-throughput screening of proteins is the protein microarray. It functions much like a cDNA microarray, but probes are constructed out of proteins, antibodies or DNA constructs containing 
protein binding sequences that can capture proteins on a chip [56].

\section{Technical pitfalls}

Technical variations are largely responsible for the low reproducibility between studies by different research groups. Differences in patient characteristics can significantly alter genomic and proteomic profiles. Proteome studies are especially difficult because proteins cannot be amplified, unlike DNA and mRNA. Therefore, scientists have to rely on fractionation, enrichment/depletion and solubilization protocols prior to MS to prevent overload with the most abundant proteins present in the serum urine

\section{Overview of genomics and proteomics in chronic liver disease}

Most chronic liver diseases lead to fibrosis and cirrhosis in a significant subset of patients. While many common pathways drive fibrogenesis in all these diseases, there are also disease-specific pathways that contribute to fibrosis. An increasing number of studies are comparing the transcriptome and proteome of patients with different types of chronic liver injury to unearth disease-specific abnormalities in gene or protein expression.

In the following section we focus on disease-specific genomic and proteomic studies in both animal models and human diseases.

\section{In vivo and in vitro animal models of fibrosis}

Not all human liver diseases can be reproduced accurately in animal models, and thus surrogate models are being developed to study mechanisms of chronic liver injury and fibrosis.

Rodent studies reviewed below have analyzed a variety of fibrosis progression and resolution models, and have evaluated liver tissue, cell isolates, serum and urine proteomes. Considerable additional effort will be required to systematically compare proteomes between different disease models, and to accomplish the translational step of comparing these proteomic changes to human liver diseases.

\section{Liver tissue proteome analysis}

A number of liver tissue proteome analyses have been reported in rodent models. Low et al. characterized the proteome of rat livers treated with thioacetamide (TAA). Using several time points, they proposed that TAA causes chronic liver injury leading to liver fibrosis through down-regulation of enzymes related to fatty acid $\beta$-oxidation, branched chain amino acids and methionine breakdown through depletion of succinylCoA and subsequent alterations in heme and iron metabolism [57]. Using carbon tetrachloride $\left(\mathrm{CCl}_{4}\right)$ as a model for toxic liver injury in mice, and Abcb4- knockout mice as a model for sclerosing cholangitis to study differentially expressed proteins in liver tissue, Henkel et al. combined DIGE with MALDI-TOF MS and peptide mass fingerprint database search. They identified 20 differentially expressed genes in the $\mathrm{CCl}_{4}$ model and 8 genes in the Abcb4-knockout model compared to control mice [58]. A number of studies have characterized proteome changes after ethanol feeding in rats. Shepard et al. observed that many mitochondrial proteins are acetylated in livers of rats that are chronically ethanol-fed [59]. A study in ethanol-fed rats treated with S-adenosylmethionine (SAM) demonstrated that the proteins affected by ethanol and SAM treatments were chaperones, beta oxidation proteins, sulfur metabolism proteins and dehydrogenase enzymes involved in methionine, glycine and choline metabolism [60]. Kharbanda et al. treated ethanol-fed rats with betaine, which restores the metabolic ratio of liver S-adenosylmethionine to S-adenosylhomocysteine. Ethanol significantly reduced carbonic anhydrase-III protein levels, which can lead to decreased resistance against oxidative stress [61].

Rodent studies are also being used as models for fibrosis resolution after the chronic injury is removed. Liu et al. characterized liver tissue proteome changes during spontaneous recovery after TAA-induced micronodular cirrhosis in rats. Using 2-DE and MALDI-TOF, they identified the up-regulation of GST-P2 that peaked after two weeks of recovery [62].

Employing a cDNA microarray gene chip and 2DDIGE with MALDI-TOF/MS-MS, Kirpich et al. found that glutathione S-transferases mu-1, pi-1 and seleniumbinding protein 2 are decreased at both gene and protein levels in a mouse model of NAFLD [63].

Enoyl-coenzyme A hidratase, an enzyme that catalyzes the second step of mitochondrial fatty acid beta-oxidation, has been described by Zhang et al. to be downregulated in rats with HFD-induced hepatic steatosis [64].

\section{Hepatic stellate cell proteome analysis}

Activation of HSCs is a key event in fibrogenesis and can be reproduced in vitro by prolonged culture on plastic or collagen. The changes in protein expression during activation can provide novel targets for antifibrotic therapy. However, differences between in vitro and in vivo HSC activation need to be taken into account. Kristensen et al. isolated hepatic stellate cells from rats and compared the proteome of quiescent cells with that of either culture-activated cells or in vivo activated cells from rats treated with $\mathrm{CCl}_{4}$ for eight weeks. Following 2-DE, proteins were digested by trypsin, and ESI-MS/MS was used to sequence the proteins that were differentially expressed. They detected 16 proteins showing differences based on the model of activation [65]. 
A study by Kawada et al. explored the proteome of in vivo (thioacetamide) and in vitro activated rat HSCs, describing a protein that was induced with HSC activation: stellate-cell activation-associated protein (STAP), which may act as an anti-fibrotic scavenger of peroxides during liver injury [66].

Deng et al. employed human hepatic stellate cells (LX2) treated and untreated with taurine and performed a combination of two-dimensional gel electrophoresis and ultra-performance liquid chromatography-electrospray ionization-tandem mass spectrometry (UPLC-ESIMS/MS). They postulate a beneficial role of taurine in hepatic fibrosis, as they were able to detect an increased rate of stellate cell apoptosis after treatment [67].

\section{Serum and urinary proteome analysis}

Animal models could provide general serum markers that correlate with fibrosis stage and have the advantage of easier access to liver tissue at set time points for histological comparison. In thioacetamide (TAA) and bileduct ligation treated rats, $\mathrm{Xu}$ et al. indentified and sequenced a $3.5 \mathrm{kDa}$ histidine-rich glycoprotein, which had $>92 \%$ specificity and $>97 \%$ sensitivity for identifying liver cirrhosis. Previous studies have shown a beneficial effect of bone marrow cell (BMC) transplantation in $\mathrm{CCl}_{4}$-induced cirrhosis in mice, improving liver regeneration, function and fibrosis. Yokoyama et al. found six differentially expressed proteins in the serum by 2-DE, 48 hours after BMC transplantation, compared to nontransplanted mice. They suggested ApoA1 protein levels as a proteomic analysis of serum marker proteins in recipient mice with liver cirrhosis after bone marrow cell transplantation. marker for liver regeneration after BMC transplantation [68]. Serum taurocholic acid has also been recently proposed as a marker of early hepatic damage based on the Shimada et al. study. The identified elevated serum taurocholic acid concentration by SPE-MALDI-TOF MS in mice $\mathrm{CCl}_{4}$ induced liver injury [69].

A recent publication looked at urinary samples to find biomarkers for $\mathrm{CCl}_{4}$-induced liver fibrosis providing a potential alternative to serum samples for non-invasive diagnostics and follow-up in liver fibrosis (70).

\section{Chronic hepatitis C viral infection (HCV)}

In patients with $\mathrm{HCV}$, early knowledge of which patients have rapidly progressing fibrosis could be very beneficial in the decision-making process of whether to treat patients aggressively with antiviral therapy. A recent review by Walters and Katze explored the relationship among the gene expression profile of HCV patients, viral clearance and treatment response, shedding light on potential virus-host interactions, which may emerge as future therapeutic targets [71].

\section{Staging of fibrosis}

The liver proteome of $\mathrm{HCV}$-patients can provide $\mathrm{HCV}$ specific and general fibrotic pathways that could lead to novel therapeutic targets, or predict the natural disease progression or therapeutic response in the individual patient. Recent findings point towards alterations in fatty acid oxidation, oxidative phosphorylation and structural proteins in advanced fibrosis. An overview of high-throughput studies analyzing pathways and proteins involved in fibrosis due to $\mathrm{HCV}$ is represented in Table 1.

Diamond et al. have described a pattern of 210 proteins that correlate with fibrosis stage in 1,641 HCVinfected patients. They were able to cluster the patients in fibrosis stages 3 to 4 versus stages 1 to 2 using these protein expression profiles. Functional analysis indicated reduced expression of genes involved in fatty acid oxidation and oxidative phosphorylation in advanced fibrosis [72]. Several cell structure-associated proteins were uncovered in the cirrhotic septa of seven HCV patients (METAVIR stage F4) when Mölleken et al. compared the proteomic profiles of microdissected cirrhotic septa versus parenchymal liver cells using 2-DE and LC with ESI-MS/MS, in the search for new serum biomarkers for fibrosis. MFAP-4 could predict the presence of fibrosis with high accuracy in both HCV - and alcoholinduced fibrosis, but diagnostic accuracy decreased significantly for the discrimination between fibrosis stages 2 to 4 [73].

Regarding serum markers, none of these serum markers can adequately distinguish intermediate fibrosis stages, even though the progression from mild to intermediate fibrosis is an important predictor of further fibrosis progression. White et al. reported three upregulated proteins ( $\alpha 2$-macroglobulin, haptoglobin, albu$\mathrm{min}$ ) and four down-regulated proteins (complement $\mathrm{C}$ 4 , serum retinol binding protein, apolipoprotein $\mathrm{A} 1$, and two isoforms of apolipoprotein A4) in the serum of $\mathrm{HCV}$ patients with advanced fibrosis (METAVIR stage $\mathrm{F} 3 / 4, \mathrm{n}=23$ ) versus no or mild fibrosis (METAVIR stage $\mathrm{F} 0 / 1, \mathrm{n}=21$ ) [74]. Three of these proteins are already being used in the FibroTest [75]. This study was limited by a small sample size, and the four new potential biomarkers could not be validated in a larger patient group. Gangadharan et al. found a decrease in several proteins, including apolipoprotein L1, prealbumin, albumin, haptoglobin and complement components, whereas other proteins, such as CD5 antigen-like (CD5L), 2macroglobulin and immunoglobulin components, were induced in fibrosis when they studied the serum proteome of $\mathrm{HCV}$ patients with varying levels of fibrosis and healthy controls, using 2-DE and LC with Q-TOF MS/MS [76]. 
Table 1 High-throughput studies in HCV patients analyzing differential gene expression based on fibrosis stage

\begin{tabular}{|c|c|c|c|c|c|c|c|c|c|c|}
\hline $1^{\text {st }}$ author & Year & $\begin{array}{c}\# \\
\text { Patients }\end{array}$ & $\begin{array}{c}\# \\
\text { Controls }\end{array}$ & Specimen & Methods & $\begin{array}{c}\# \\
\text { Differentially } \\
\text { expressed } \\
\text { genes }\end{array}$ & $\begin{array}{l}\text { Main pathways } \\
\text { involved }\end{array}$ & $\begin{array}{c}\text { Most } \\
\text { differentially } \\
\text { regulated genes }\end{array}$ & $\Uparrow / \Downarrow$ & Reference \\
\hline Huang & 2006 & 121 & 312 & Blood & $\begin{array}{l}\text { SNP } \\
\text { microarray }\end{array}$ & 1,609 & N/A & $\begin{array}{l}\text { DEAD-box } \\
\text { popypeptide } 5 \\
\text { (DDX5) SNP } \\
\text { Carnitine } \\
\text { palitoyltransferase } \\
\text { 1A (CPT1A) SNP }\end{array}$ & $\begin{array}{l}\Uparrow \\
\Uparrow\end{array}$ & 81 \\
\hline Diamond & 2007 & 22 & 4 & Liver tissue & $\begin{array}{l}\text { LC-ESI- } \\
\text { FTICR MS/ } \\
\text { MS }\end{array}$ & 210 & $\begin{array}{l}\text { Amino acid, } \\
\text { carbohydrate and } \\
\text { lipid metabolism } \\
\text { Oxidative } \\
\text { phosphorylation } \\
\text { Oxidative stress }\end{array}$ & N/A & $\begin{array}{l}\text { N/A } \\
\text { N/A } \\
\text { N/A }\end{array}$ & 72 \\
\hline White & 2007 & 23 & 21 & Serum & $\begin{array}{l}\text { 2-DE/LC- } \\
\text { Q-TOF } \\
\text { MS/MS }\end{array}$ & 7 & N/A & $\begin{array}{l}\text { Alpha-2- } \\
\text { macroblobulin } \\
\text { Haptoglobin } \\
\text { Fragment of } \\
\text { albumin } \\
\text { Serum retinol } \\
\text { binding protein } \\
\text { (SRBP) } \\
\text { Complement } 4 \\
\text { Apolipoprotein A-I } \\
\text { (Apo A1) } \\
\text { Apolipoprotein A- } \\
\text { IV (Apo A4) }\end{array}$ & $\begin{array}{l}\Uparrow \\
\Uparrow \\
\Uparrow \\
\Downarrow \\
\Downarrow \\
\Downarrow \\
\Downarrow\end{array}$ & 74 \\
\hline Gangadharan & 2007 & 11 & 4 & Serum & $\begin{array}{l}\text { 2-DE-Q- } \\
\text { TOF/ } \\
\text { CapLC } \\
\text { MS/MS }\end{array}$ & 83 & $\begin{array}{l}\text { Plasmin-associated } \\
\text { Hepatic synthetic } \\
\text { function HGF- } \\
\text { releated Lipid } \\
\text { metabolism Immune } \\
\text { system related }\end{array}$ & $\begin{array}{l}\text { Alpha-2- } \\
\text { macroblobulin } \\
\text { Inter-alpha-trypsin } \\
\text { inhibitor heavy } \\
\text { chain } 4 \\
\text { Albumin } \\
\text { Transthyretin } \\
\text { Complement C3 } \\
\text { and C4 } \\
\text { Factor H-related } \\
\text { protein } 1 \\
\text { Alpha-1 } \\
\text { antichymotrypsin } \\
\text { Haptoglobin } \\
\text { Apolipoprotein L-I } \\
\text { Beta } 2 \\
\text { glycoprotein } \\
\text { CD5 antigen like } \\
\text { IgA1+lgG2 heavy } \\
\text { chain and Ig light } \\
\text { chain regions }\end{array}$ & $\begin{array}{l}\Uparrow \\
\Downarrow \\
\Downarrow \\
\Downarrow \\
\Downarrow \\
\Downarrow \\
\Downarrow \\
\Downarrow \\
\Downarrow \\
\Downarrow \\
\Uparrow \\
\Downarrow \\
\Downarrow \\
\Uparrow \\
\Uparrow\end{array}$ & 76 \\
\hline Mölleken & 2009 & 7 & 7 & microdissections & $\begin{array}{l}\text { 2-DE/LC- } \\
\text { ESI-Ion } \\
\text { trap MS/ } \\
\text { MS }\end{array}$ & 35 & Cell structure & $\begin{array}{l}\text { Tropomyosin } \\
\text { alpha } \\
\text { Tropomyosin beta } \\
\text { Microfibtil- } \\
\text { associated } \\
\text { glycoprotein } 4 \\
\text { Calpoin } 1 \\
\text { Transgelin } \\
\text { Tropomyosin } \\
\text { alpha } 4 \\
\text { Actin alpha } 1 \\
\text { Vimentin }\end{array}$ & $\begin{array}{l}\Uparrow \\
\Uparrow \\
\Uparrow \\
\Uparrow \\
\Uparrow \\
\Uparrow \\
\Uparrow \\
\Uparrow\end{array}$ & 73 \\
\hline
\end{tabular}


A novel set of four cDNA peripheral blood mononuclear cell markers (a2-macroglobulin, haptoglobin, mitogen-activated protein kinase kinase 3 , and alanine aminopeptidase N) accurately predicted the stage of liver fibrosis in $\mathrm{HIV} / \mathrm{HCV}$ co-infected patients with an area under the receiver operating curve (AUC ROC) of 0.852 [77].

L Yang et al. recently analyzed 24 liver samples from patients with chronic HCV by DIGE and Isobaric tags for relative and absolute quantitation (iTRAQ) and identified 2 proteins as biomarker candidates for predicting hepatic fibrosis: complement $\mathrm{C} 4-\mathrm{A}$ and inter-alpha-trypsin inhibitor heavy chain H4 [78,79].

\section{Novel biomarker candidates to predict hepatic fibrosis in hepatitis c identified by serum proteomics}

Fibrosis progression has also been related to galectin-3binding protein (G3BP). Cheung et al. found increased levels in patients with hepatitis C-related cirrhosis when compared with mild and moderate fibrosis in 76 serum and 20 tissue human samples [80].

\section{Prediction of fibrosis progression}

Prediction of fibrosis progression is crucial for adequate patient selection in clinical trials, and, thus, Huang et al. studied the genome of 1,468 patients with chronic hepatitis $\mathrm{C}$ infection and known fibrosis stage. They developed a Cirrhosis Risk Score (CRS) consisting of SNPs in seven genes, which could predict fibrosis progression significantly better than clinical parameters. Four SNPs were in known genes: antizyme-inhibitor-1, toll-like receptor 4, transient receptor potential cation channel, subfamily $M$, member 5 and aquaporin 2 [81]. This initial study was independently validated two additional studies [82,83], and is especially exciting, as it is the first evidence that host genetics significantly influence fibrosis progression and, thereby, provides a means for selecting patients that will benefit most from aggressive antiviral or antifibrotic treatment.

At the proteomic level, when plasma from cirrhotic HCV patients is analyzed by SDS-PAGE and MS, both chains of the complement $\mathrm{C} 3$ and $\mathrm{C} 4$ show a significant decrease in comparison with samples from healthy patients $[84,85]$.

\section{Prediction of treatment response}

Transcriptomic and proteomic studies point to a crucial role of interferon signaling pathways in the prediction of treatment response, where high pre-treatment interferon signaling is associated with poor virological response. Recent genomic studies have identified SNPs in several interferon-related genes, especially interleukin $28 \mathrm{~b}$, that are powerful predictors of virologic response indicating that genomics can be a powerful tool in the prediction of treatment response.
A recent publication by Asselah et al. demonstrated that liver gene expression can predict outcome of patients with chronic hepatitis $\mathrm{C}$ infection after treatment with pegylated interferon and ribavirin. They studied cDNA of non-responders (NR), and SVR using RTPCR for 59 genes. Three genes were significantly induced in NRs versus SVRs: interferon alpha-inducible protein 3, interferon alpha-inducible protein 27 and interferon alpha-inducible protein 2. Supervised class prediction analysis identified a two-gene (interferonalpha-inducible protein 27 and CXC chemokine ligand 9) signature, with a predictive accuracy of $100 \%$ in NRs and of $70 \%$ in SVRs. Although no high-throughput analysis was performed, this paper provides a basis for further exploring the use of genomic and proteomic information to predict individual treatment response, and may be useful for selecting those patients who will benefit from treatment [86].

Chen et al. analyzed liver tissue using cDNA microarray to identify a gene signature that can predict treatment outcome. A key finding was that interferon stimulated gene 15 (ISG15) protein induction was more pronounced in hepatocytes in non-responders, but in Kupffer cells in responders [75]. In a liver tissue microarray study by Hayashida et al., a different set of genes was found to predict treatment response in patients treated with interferon alone, or interferon/ribavirin cotreatment. In the interferon monotherapy patients, main predictors were genes involved in the interferon signaling pathway, lipid metabolism, complement and oxidation/reduction. In the combined treatment group, genes, including cylophylin $A$, and multidrug resistance protein-hepatic gene expression during treatment with peginterferon and ribavirin emerged, identifying molecular pathways for treatment response. 1 (P-gp) [87]. Feld et al. discovered that low baseline liver tissue cDNA levels of interferon-stimulated genes (ISGs) predict rapid treatment response with quick induction of ISG levels, whereas high baseline ISG levels do not increase much further and predict slow treatment response, together with up-regulation of interferon inhibitory pathways [88].

As described above, recent genome-wide association studies (GWAS) have identified SNPs in the interleukin 28b (IL28B, coding for interferon- $\gamma-3$ ) genomic region that are associated with viral response to the current treatment of $\mathrm{HCV}$, pegylated-interferon-alpha (PEGIFN $\alpha$ ) and ribavirin. GWAS by Suppiah et al. led to the discovery of a SNP near interleukin 28b (IL28B) that is associated with sustained viral response (SVR) in genotype $1 \mathrm{HCV}$ patients treated with PEG-IFN $\alpha$ and ribavirin, with an odds ratio (OR) for the G-allele of rs8099817 of 1.64 for heterozygous carriers and 2.39 for 
homozygous carriers compared to non-carriers [89]. Other SNPs that were associated with SVR included Caspase 1, a known activator of interleukin 1, and interleukin 21 receptor. A simultaneous report was published by Tanaka et al., identifying SNPs in IL28B in a Japanese genotype $1 \mathrm{HCV}$-patient cohort as a predictor of virologic response to PEG-IFN $\alpha$ and ribavirin. Initial GWAS identified rs2980275 and rs8099917 SNPs as predictors of non-response and SVR. They continued to seek SNPs in the IL28A/B region and uncovered rs8105790, rs11881222, rs8103142, rs28416813, rs4803219, rs8099917 and rs7248668 as associated with virologic response [90]. Identification of those HCVpatients who are likely to respond to therapy could lead to a shortened duration of therapy in patients with a favorable SNP genotype. Although these studies did not examine fibrogenic end-points, they are a major breakthrough in $\mathrm{HCV}$ treatment response research, and are excellent examples of how GWAS can identify genes and SNPs that are related to therapeutic responses.

Non-responders generally have high expression of interferon-stimulated genes (ISGs) pre-treatment that cannot be further induced by PEG-IFN $\alpha$, whereas RVR patients have strong induction of ISGs on treatment. Refractory high endogenous interferon signaling in nonresponders may interfere with PEG-IFN $\alpha$ treatment, especially in genotype 1 and 4 patients. Whether inhibition of endogenous interferon signaling could improve therapeutic response is subject to further study [91,92].

Although further validation is needed, Devitt $\mathrm{E}$ et al. using SELDI-TOF MS analyzed serum from $25 \mathrm{HCV}$ infected patients during the initial $24 \mathrm{~h}$ of treatment with pegylated interferon $\alpha-2 b$ and ribavirin and identified 16 differential peaks able to distinguish responders from nonresponders [93].

\section{Chronic hepatitis B viral infection (HBV)}

Approximately 400 million patients worldwide are chronically infected with hepatitis B virus (CHB). Hepatitis $B$ virus infection causes chronic hepatitis in about $10 \%$ of infected patients, and increases the risk of developing HCC about 100-fold versus in the uninfected population. An excellent review on the role of genomics, transcriptomics and proteomics in chronic HBV-associated liver disease, recently published by Sun et al., described determinants of susceptibility to persistent HBV infection, disease progression and HCC development; their review also describes the use of these technologies to understand the pathogenic mechanism of HBV and to identify biomarkers that could aid in early detection of HCC [94].

Recent high-throughput proteomic studies have identified protein patterns that correlate with fibrosis stage in HBV patients. Zhang et al. described a novel approach to evaluate the protein expression profile of plasma membrane and analyzed human liver samples from HBV patients in different fibrosis stages. Using 2-DE, IPGphor isoelectronic focusing system and Bio-Rad Protein II electrophoresis to the investigators identified positive correlation between fibrosis grade and annexin A2 levels [95]. Lu et al. analyzed plasma of 7 healthy controls and $27 \mathrm{HBV}$ patients with different stages of fibrosis by 2-DIGE and identified the up-regulation of peroxiredoxin 2 as a potential biomarker of HBV related liver fibrosis [96]. Although not liver-specific, plasma gelsolin protein has been pointed out as a potential predictor of HBV progression. C Marrocco et al. found by 2-DE a repressed expression of the protein in plasma of eight cirrhotic HBV patients, compared to eight chronic HBV infected patients [97]. Mohamadkhani et al. performed a $2 \mathrm{DE}$ and mass spectrometry analysis in patients with either chronic hepatitis B or HBV-related cirrhosis and healthy controls. Their data suggest that progression of HBV-related liver injury is associated with a down-regulation of apolipoprotein A1 and an increase in myeloperoxidase levels [98]. However, these results still need to be validated, and their ability to distinguish intermediate fibrosis stages is not clear.

Poon et al. using SELDI ProteinChip arrays and the Significance Analysis of Microarray (SAM) algorithm generated a model able to predict fibrosis (Ishak score $\geq$ 3 ) and cirrhosis (Ishak score $\geq 5$ ) with an accuracy of $>$ 90\% [99]. Liver histology (METAVIR score) of HBVpatients was compared with three sets of serum markers by Myers et al:: aminotransferases (ALT, AST), Fibrotest $\left(\alpha_{2}\right.$-macroglobulin, apolipoprotein A1, haptoglobin, gamma-glutamyl-transpeptidase (GGT) and total bilirubin) and Actitest (ALT). Aminotransferases and Actitest were good predictors of activity (stage A2-F3) and Fibrotest accurately predicted stage F2-F4 fibrosis, especially in the ranges of $\leq 0.20$ or $>0.80$. Limiting liver biopsy to patients with intermediate Fibrotest scores could prevent biopsies in about half of the patients, without affecting accuracy [100].

Wang et al. performed an in vitro study to investigate proteome differences between stably HBV transfected HepG2.2.15 versus wild type HepG2 cells by 2-DE followed by LC-ESI-MS/MS. Furthermore; they compared HepG2.2.15 cells with and without interferon-alpha $(I F N-\alpha)$ treatment. Proteins that were differentially expressed in HepG2.2.15 versus HepG2 cells could be classified as being involved in, for example, cytoskeletal matrix, heat shock stress, signal transduction and protease/proteasome components. IFN- $\alpha$ treatment induced expression of interferon-stimulated gene 15 (ISG15) and prohibitin, among others, providing potential pathways that could lead to tumor suppression and defense against viral infection. Although these results have not 
been validated in vivo, they nevertheless establish that proteomics and cell culture can be a powerful combination to uncover differences in the proteome, and can be useful for evaluating potential treatments [101].

\section{Alcoholic liver disease (ALD)}

Several genomic and proteomic studies have been published on patients with alcoholic liver disease. However, the majority of studies focus on either diagnostics or genes/proteins that differentiate alcoholic hepatitis from alcoholic steatosis, not in predicting progression towards fibrosis and cirrhosis. Nevertheless, alcoholic steatohepatitis is clearly a precursor for developing fibrosis. For example, 586 genes were differentially expressed between alcoholic hepatitis and alcoholic steatosis, and 211 genes were differentially expressed between alcoholic hepatitis and non-disease controls when Seth et al. compared liver tissue RNA from eight patients with alcoholic hepatitis, nine with alcoholic steatosis, and seven non-disease controls using microarray analysis. Induced genes included pathways controlling cell adhesion, immune response, oncogenesis, signal transduction and embryogenesis. The 111 down-regulated genes included pathways for protein synthesis, cell growth and maintenance, transcription, signal transduction and transport [102].

\section{Non-alcoholic fatty liver disease (NAFLD) and non- alcoholic steatohepatitis (NASH)}

The prevalence of NAFLD and NASH is on the rise, which makes these increasingly important causes of liver fibrosis, especially in countries with a Western diet containing a high fat and/or carbohydrate content. For NAFLD and NASH there is also a lack of genomic/proteomic studies specifically examining fibrogenesis and fibrosis progression, much like in alcoholic liver disease. Most genomic/proteomic studies focus on distinguishing NASH from NAFLD, and not on progression to liver fibrosis and cirrhosis. The ability to distinguish NASH from NAFLD is very relevant, however, as NASH clearly predisposes to fibrosis. Therefore, we reviewed recent publications on this topic. However, studies directed at identifying proteins related to the speed of fibrosis progression in NASH could further select patients who could benefit from treatment, improve understanding of fibrosis pathogenesis in fatty liver, and identify targets for treatment of NASH-related fibrosis.

\section{Staging of steatosis}

$\mathrm{NASH}$ is distinguished from NAFLD by an inflammatory component. Therefore, not surprisingly, genes that are up-regulated in NASH versus NAFLD have strong relationships with inflammatory and immune pathways. Complementary DNA microarray analysis on nine liver tissue samples from steatotic livers and nine normal livers unearthed 110 differentially expressed genes, many related to mitochondrial respiratory and mitochondrial metabolic pathways. Genes belonging to the interleukin1 receptor family and transforming growth factor-beta were induced in steatotic livers, pointing to a deranged inflammatory pathway, even in early development of steatosis. Thirty-four genes with significant differential expression were identified in patients with NASH, when compared with non-obese controls in a study by Younossi et al., using cDNA microarray analysis on liver biopsies taken during bariatric surgery to find differential expression patterns between NASH $(n=29)$, NAFLD $(n=12)$, obese non-steatotic $(n=7)$, and nonobese controls $(n=6)$ [103]. Nineteen of these genes showed no significant expression differences in obese versus non-obese controls, suggesting a stronger association of these genes to NASH. These genes were related to lipid metabolism, extracellular matrix remodeling, liver regeneration, apoptosis and detoxification. In another study, this group used parallel liver tissue gene expression and serum proteome analysis in a group of 98 morbidly obese patients. Twenty-seven patients had developed NASH, 52 patients had steatosis with nonspecific inflammation, 12 patients had steatosis alone and 7 patients had normal histology on biopsy. Using SELDITOF analysis on serum samples, this group found several protein peaks associated with different stages of NAFLD/NASH. However, except for fibrinogen $\gamma$, the corresponding proteins were not identified. On the mRNA level, insulin-like growth factor binding protein 1 (IGFBP1) and fatty acid CoA ligase 4 (FACL4) were differentially expressed between NASH and steatotic patients.

A recent study of the serum proteome by Bell et al. led to the discovery of 55 proteins that changed significantly between simple steatosis and NASH with stage F3/F4 fibrosis (advanced bridging fibrosis/cirrhosis), and 15 proteins that changed between early NASH and NASH with stage F3/F4 fibrosis. Most of these proteins are involved in the immune response, coagulation, cellular and extracellular matrix and blood carrier proteins [104]. These proteins shed light on the pathogenesis of NAFLD/NASH and could be explored as candidates for biomarkers of advancing disease. Ulukaya et al. were able to use serum MALDI-TOF MS peaks to accurately predict NAFLD versus controls, but could not distinguish between simple steatosis and NASH. They included 80 patients with NAFLD, and 19 controls [105]. Histologic classification of the NAFLD patients showed definite NASH in 48 patients, borderline NASH in 22 patients and 10 patients with simple steatosis. Using reverse phase protein microarray technology, Calvert et al. revealed deranged insulin signaling in NAFLD patients when they investigated omental adipose tissue 
from 99 obese patients. Liver biopsies were classified as follows: (1) no fatty liver disease present, (2) simple steatosis, (3) steatosis with nonspecific inflammation, or (4) NASH. Categories 2 to 4 were clustered as NAFLD. Protein kinase A (PKA) and AKT/mTOR deregulation and caspase 9 activation were good predictors of $\mathrm{NASH}$ on liver histology compared to non-progressive forms of NAFLD [106]. For more information on genomic and proteomic analysis of NAFLD and NASH, see a recent review by Wilfred de Alwis and Day [107].

\section{Fibrosis progression in steatotic patients}

Very few publications report changes in gene expression that correlate with fibrosis stage in NAFLD/NASH patients. So far, only apolipoproteins, CD5 antigen-like (CD5L) and lumican have been identified. Gray et al. applied 2-DE and MALDI-TOF to analyze differences in serum proteome profile between patients with pre-cirrhotic NAFLD $(\mathrm{n}=5)$, cirrhotic NAFLD $(\mathrm{n}=5)$ and cirrhotic NAFLD with HCC $(n=5)$. Four out of five spots that identified at least one of the three groups were identified as apolipoprotein isoforms. The fifth spot, identified as CD5L, was induced in cirrhotic patients and even more in patients with HCC. ELISA analysis of CD5L in a larger patient group showed a poor AUROC score for distinguishing patients with HCC from those without HCC. However, as a cirrhosis biomarker, ROC analysis showed an accuracy of $72 \%$. CD5L could potentially be used in combination with other biomarkers for cirrhosis [108]. Charlton et al. identified lumican, a 40 $\mathrm{kDa}$ keratin sulfate proteoglycan, as significantly increased in liver tissue from patients with mild NASH (NASH with F0/F1 fibrosis) versus simple steatosis, and in patients with progressive NASH (NASH with F2-F4 fibrosis) versus mild NASH in obese patients, when analyzed with LC-Q-TOF MS/MS. FABP-1 was increased in simple steatosis patients compared to non-steatotic patients, but was paradoxically decreased in NASH patients, which suggests an impaired detergent effect against free fatty acids in progressive NAFLD patients [109].

\section{Autoimmune liver diseases}

Primary biliary cirrhosis (PBC), as well as related autoimmune disorders, is more prevalent in certain families and thus seems to have a complex genetic component, with many factors probably adding to the risk of developing PBC. Some of these genes associated with PBC are major histocompatibility complex genes and common autoimmune genes [110]. Shackel et al. discovered that PBC liver tissue had increased expression of Th1 and Th2 type proteins as well as connective tissue growth factor and TGF- $\beta 3$ when they analyzed their cDNA microarray from liver tissue from patients with PBC $(\mathrm{n}=4), \operatorname{PSC}(\mathrm{n}=4)$ and non-disease controls ( $\mathrm{n}=$
8). Moreover, Wnt and Notch signaling pathways were induced. PSC patient samples had increased expression of apoptosis associated molecules [111]. Serum samples from 44 PBC patients and 75 controls, analyzed using WCX magnetic beads and MALDI-TOF-MS, provided 69 potential protein biomarkers. Li et al. used these to construct a diagnostic model for PBC using the $\mathrm{m} / z$ peaks of protein biomarkers $3445,4260,8133$, and 16290 , which showed a sensitivity of $92.9 \%$ and a specificity of $82.4 \%$ [112].

Tahiri et al. noticed an induction of six known potential plasma membrane expressions: liver arginase, cytokeratins 8/18, heatshock proteins (HSP) 60/70/90, and valocin-containing protein (VCP) in autoimmune hepatitis when they investigated serum samples from 65 autoimmune hepatitis type 1 patients and 90 controls consisting of healthy blood donors $(n=40)$ and patients with systemic diseases $(n=20)$ or other liver diseases $(n$ $=30$ ). They proposed that these proteins could be targets for auto-antibodies in autoimmune hepatitis [113]. Using protein microarray, Song et al. analyzed serum samples from patients with autoimmune hepatitis ( $\mathrm{n}=$ $44)$, PBC ( $\mathrm{n}=50), \operatorname{HCV}(\mathrm{n}=41)$, HBV ( $\mathrm{n}=43)$, systemic lupus erythematosus (SLE) $(\mathrm{n}=11)$, primary Sjögren syndrome $(n=11)$, rheumatoid arthritis $(n=2)$ and 50 healthy controls. Initially they found 11 differentially expressed genes between autoimmune hepatitis and other samples. They then produced an autoimmune hepatitis-specific protein chip, and found three new antigens, ribosomal protein S20 (RPS20), Alba-like, and dUTPase, that could be used as highly specific biomarkers for autoimmune hepatitis, and validated this with ELISA [114]. Bowlus et al. have recently analyzed by in situ MALDIMS (matrix-assisted laser desorption/ionization mass spectrometry) in PBC ( $\mathrm{n}=29)$, PSC $(\mathrm{n}=11)$, AIH $(n=7)$ and healthy controls $(n=10)$ and found a promising pattern of protein expression in bile ducts, inflammatory infiltrates and hepatocytes that may represent a feasible way to identify novel targets in these diseases [115]. Song et al. created a protein microarray containing 5,011 recombinant human liver proteins and were able to identify three new antigens, RPS20, Albalike and dUTPase, as highly autoimmune hepatitis-specific biomarkers [114].

Although these results are promising, the number of high-throughput genomic and proteomic studies in autoimmune liver diseases is still very limited.

\section{Hepatocellular carcinoma}

While beyond the scope of this review, there have been significant advances in early diagnosis, treatment and pathway analysis of $\mathrm{HCC}$ and hepatocarcinogenesis through genome, transcriptome and proteome highthroughput analysis, especially in the setting of liver 
cirrhosis. For more information on this topic we refer to recent reviews [116-118].

\section{General conclusions and future directions}

In the last decade, genomic and proteomic hypothesisfree studies have become increasingly common. Since liver fibrosis often takes many years to develop, and not every patient will become symptomatic, a method to select patients who will benefit from aggressive treatment in an early phase would be very beneficial. Therefore, there is a demand for biomarkers that can provide a prognostic indication for fibrosis, either in the natural course of chronic liver disease, or as a predictor of treatment response. Liver biopsy is currently the gold standard for follow-up in chronic liver disease, but it can have serious complications and suffers from sampling error and inter-observer variation. This drives the search for non-invasive direct or indirect biomarkers that correlate accurately with fibrosis stage.

Prospective predictive proteomic and genomic studies are difficult in liver disease, as follow-up is long, and biological samples can degrade over time. Thus far, many tests based on serum biomarkers correlate fairly well with the fibrosis stage when advanced fibrosis (METAVIR F3-4) is compared to mild or no fibrosis (F0 to 2), but lack resolution in the intermediate stages. Especially, these intermediate stages (F1 to 2) could be helpful in the early detection of progressive fibrosis and guide the hepatologist in treatment decisions. So far, genomic and proteomic studies for fibrosis staging have been mostly limited to viral hepatitis, with other diseases like alcoholic liver disease and NASH yet to be explored. Studying the fibrotic genome/proteome in these diseases will shed light on common and distinct pathological pathways leading to liver fibrosis.

Genomic and proteomic studies that have identified genes and proteins that correlate with fibrosis levels have yielded heterogeneous findings, most likely due to variations in sample preparations and patient populations/characteristics. The lack of standardized sample preparation protocols hinders reproducibility of protein spectra. A few gene and protein groups seem to correlate with fibrosis more consistently, mostly belonging to glutathione, oxidative stress, inflammatory and immune response pathways. For most of the identified proteins, adequate follow-up has been lacking so far, leaving scientists with lots of potential biomarker candidates still in need of validation.

Future high-throughput research will continue uncovering genes and proteins that can elucidate common and specific-disease pathways that lead to liver fibrosis. Standardization of sample preparation protocols should increase reproducibility of these studies, and will make it easier to select candidate genes and proteins that are suitable for validation as biomarkers for either fibrosis staging, or as predictive biomarkers for disease outcome and/or treatment response.

\section{Abbrevations}

2-DE/2D-PAGE: 2D-polyacrylamide gel electrophoresis; AlH: autoimmune hepatitis; ALD: alcoholic liver disease; BMC: bone marrow cell; $\mathrm{CCl}_{4}$ : carbon tetrachloride; CRS: Cirrhosis Risk Score; DIGE: gel electrophoresis; ESI: electrospray ionization; FACL4: fatty acid CoA ligase 4; FT-ICR: Fourier transformion cyclotron resonance; GWAS: genome-wide association studies; HCC: hepatocellular carcinoma; HCV: chronic hepatitis c viral infection; HSCs: hepatic stellate cells; IGFBP1: insulin-like growth factor binding protein 1; IMAC: immobilized metal affinity capture; ISGs: interferon-stimulated genes; iTRAQ: isobaric tags for relative and absolute quantitation; LC: liquid chromatography; MALDI: matrix-assisted laser desorption/ionization; MALDIMS: matrix-assisted laser desorption/ionization mass spectrometry; MS: mass spectrometry; m/z: mass-to-charge; NAFLD: non-alcoholic fatty liver disease; NASH: non-alcoholic steatohepatitis; OR: odds ratio; PBC: primary billiary cirrhosis; PCR: polymerase chain reaction; PKA: protein kinase A; Q-Q-TOF: second quadruple time-of-flight; Q-TOF: quadruple time-of-flight; RT-qPCR: reverse transcription quantitative PCR; SAGE: serial analysis of gene expression; SAM: significance analysis of microarray; SAX: strong anion exchange; SELDI: surface-enhanced laser desorption/ionization; SNPs: single nucleotide polymorphisms; STAP: stellate-cel activation-associated protein; SVR: sustained viral response; TAA: thioacetamide; TIMP-1: tissue inhibitor of metalloproteinases-1; TOF: time-of-flight; UPLC-ESI: ultra-performance liquid chromatography-electrospray ionization-tandem; WCX: weak cation exchange

\section{Acknowledgements}

$\mathrm{RH}$ was funded by the Graduate School for Drug Exploration (GUIDE), and the Stichting Nicolaas Muleriusfonds, Groningen, the Netherlands. SF and VH-G are supported by NIH Grants DK37340, DK56621 and AA017067.

\section{Author details}

'Department of Medicine/Division of Liver Diseases, Mount Sinai School of Medicine, New York, NY 10029, USA. ²Department of Gastroenterology and Hepatology, University Medical Center Groningen, University of Groningen, Groningen, The Netherlands.

\section{Authors' contributions}

$\mathrm{RH}$ participated in the design of the study, carried out the bibliographic search, drafted the manuscript and created the tables. VHG participated in the design of the study, the bibliographic search and the manuscript drafting. SF conceived of the study, participated in its design and coordination, and helped to draft the manuscript. All authors read and approved the final manuscript.

\section{Competing interests}

The authors declare that they have no competing interests.

Received: 28 October 2011 Accepted: 3 January 2012

Published: 3 January 2012

\section{References}

1. Bataller R, Brenner DA: Liver fibrosis. J Clin Invest 2005, 115:209-18.

2. Friedman SL: Hepatic stellate cells: protean, multifunctional, and enigmatic cells of the liver. Physiol Rev 2008, 88:125-72.

3. Juran $\mathrm{BD}$, Lazaridis $\mathrm{KN}$ : Applying genomics to the study of complex disease. Semin Liver Dis 2007, 27:3-12.

4. Osterreicher $\mathrm{CH}$, Stickel F, Brenner DA: Genomics of liver fibrosis and cirrhosis. Semin Liver Dis 2007, 27:28-43.

5. Juran BD, Lazaridis KN: Genomics and complex liver disease: Challenges and opportunities. Hepatology 2006, 44:1380-90.

6. Grant A, Neuberger J: Guidelines on the use of liver biopsy in clinical practice. British Society of Gastroenterology. Gut 1999, 45(Suppl 4): IV1-IV11.

7. McGill DB, Rakela J, Zinsmeister AR, Ott BJ: A 21-year experience with major hemorrhage after percutaneous liver biopsy. Gastroenterology 1990, 99:1396-400. 
8. Piccinino F, Sagnelli E, Pasquale G, Giusti G: Complications following percutaneous liver biopsy. A multicentre retrospective study on 68,276 biopsies. J Hepatol 1986, 2:165-73.

9. Regev A, Berho M, Jeffers $\amalg$, Milikowski C, Molina EG, Pyrsopoulos NT, Feng ZZ, Reddy KR, Schiff ER: Sampling error and intraobserver variation in liver biopsy in patients with chronic HCV infection. Am J Gastroenterol 2002, 97:2614-8.

10. Siddique I, El-Naga HA, Madda JP, Memon A, Hasan F: Sampling variability on percutaneous liver biopsy in patients with chronic hepatitis $C$ virus infection. Scand J Gastroenterol 2003, 38:427-32.

11. Ratziu V, Charlotte F, Heurtier A, Gombert S, Giral P, Bruckert E, Grimaldi A, Capron F, Poynard T: Sampling variability of liver biopsy in nonalcoholic fatty liver disease. Gastroenterology 2005, 128:1898-906.

12. Cox LA, Schlabritz-Loutsevitch N, Hubbard GB, Nijland MJ, McDonald TJ, Nathanielsz PW: Gene expression profile differences in left and right liver lobes from mid-gestation fetal baboons: a cautionary tale. J Physio/ 2006, 572:59-66

13. Skripenova S, Trainer TD, Krawitt EL, Blaszyk H: Variability of grade and stage in simultaneous paired liver biopsies in patients with hepatitis $C$. $J$ Clin Pathol 2007, 60:321-4.

14. Bedossa $P$, Dargere $D$, Paradis V: Sampling variability of liver fibrosis in chronic hepatitis C. Hepatology 2003, 38:1449-57.

15. Boess F, Kamber M, Romer S, Gasser R, Muller D, Albertini S, Suter L: Gene expression in two hepatic cell lines, cultured primary hepatocytes, and liver slices compared to the in vivo liver gene expression in rats: possible implications for toxicogenomics use of in vitro systems. Toxicol Sci 2003, 73:386-402.

16. Wai CT, Greenson JK, Fontana RJ, Kalbfleisch JD, Marrero JA, Conjeevaram HS, Lok AS: A simple noninvasive index can predict both significant fibrosis and cirrhosis in patients with chronic hepatitis $C$. Hepatology 2003, 38:518-26.

17. Martinez SM, Crespo G, Navasa M, Forns X: Noninvasive assessment of liver fibrosis. Hepatology 2011, 53:325-35.

18. Imbert-Bismut F, Ratziu V, Pieroni L, Charlotte F, Benhamou Y, Poynard $T$ Biochemical markers of liver fibrosis in patients with hepatitis $C$ virus infection: a prospective study. Lancet 2001, 357:1069-75.

19. Poynard T, Imbert-Bismut F, Munteanu M, Messous D, Myers RP, Thabut D, Ratziu V, Mercadier A, Benhamou Y, Hainque B: Overview of the diagnostic value of biochemical markers of liver fibrosis (FibroTest, HCV FibroSure) and necrosis (ActiTest) in patients with chronic hepatitis C. Comp Hepatol 2004, 3:8.

20. Halfon P, Imbert-Bismut F, Messous D, Antoniotti G, Benchetrit D, CartLamy P, Delaporte G, Doutheau D, Klump T, Sala M, Thibaud D, Trepo E, Thabut D, Myers RP, Poynard T: A prospective assessment of the interlaboratory variability of biochemical markers of fibrosis (FibroTest) and activity (ActiTest) in patients with chronic liver disease. Comp Hepatol 2002, 1:3.

21. Smith JO, Sterling RK: Systematic review: non-invasive methods of fibrosis analysis in chronic hepatitis C. Aliment Pharmacol Ther 2009, 30:557-76.

22. Rockey DC, Bissell DM: Noninvasive measures of liver fibrosis. Hepatology 2006, 43:S113-20.

23. Shaheen AA, Wan AF, Myers RP: FibroTest and FibroScan for the prediction of hepatitis C-related fibrosis: a systematic review of diagnostic test accuracy. Am J Gastroenterol 2007, 102:2589-600.

24. Trinchet JC, Hartmann DJ, Pateron D, Laarif M, Callard P, Ville G, Beaugrand M: Serum type I collagen and N-terminal peptide of type III procollagen in chronic hepatitis. Relationship to liver histology and conventional liver tests. J Hepatol 1991, 12:139-44.

25. Teare JP, Sherman D, Greenfield SM, Simpson J, Bray G, Catterall AP, Murray-Lyon IM, Peters TJ, Williams R, Thompson RP: Comparison of serum procollagen III peptide concentrations and PGA index for assessment of hepatic fibrosis. Lancet 1993, 342:895-8.

26. Gallorini A, Plebani M, Pontisso P, Chemello L, Masiero M, Mantovani G, Alberti A: Serum markers of hepatic fibrogenesis in chronic hepatitis type C treated with alfa-2A interferon. Liver 1994, 14:257-64.

27. Yabu K, Kiyosawa K, Mori H, Matsumoto A, Yoshizawa K, Tanaka E, Furuta S: Serum collagen type IV for the assessment of fibrosis and resistance to interferon therapy in chronic hepatitis C. Scand J Gastroenterol 1994, 29:474-9.

28. Walsh KM, Timms P, Campbell S, MacSween RN, Morris AJ: Plasma levels of matrix metalloproteinase-2 (MMP-2) and tissue inhibitors of metalloproteinases -1 and -2 (TIMP-1 and TIMP-2) as noninvasive markers of liver disease in chronic hepatitis C: comparison using ROC analysis. Dig Dis Sci 1999, 44:624-30.

29. Boeker $\mathrm{KH}$, Haberkorn Cl, Michels D, Flemming P, Manns MP, Lichtinghagen R: Diagnostic potential of circulating TIMP-1 and MMP-2 as markers of liver fibrosis in patients with chronic hepatitis C. Clin Chim Acta 2002, 316:71-81

30. Cheung KJ, Tilleman K, Deforce D, Colle I, Van Vlierberghe H: The HCV serum proteome: a search for fibrosis protein markers. J Viral Hepat 2009, 16:418-29.

31. Morra R, Munteanu M, Bedossa P, Dargere $D$, Janneau JL, Paradis $V$, Ratziu V, Charlotte F, Thibault V, Imbert-Bismut F, Poynard T: Diagnostic value of serum protein profiling by SELDI-TOF ProteinChip compared with a biochemical marker, FibroTest, for the diagnosis of advanced fibrosis in patients with chronic hepatitis C. Aliment Pharmacol Ther 2007, 26:847-58

32. Gressner OA, Weiskirchen R, Gressner AM: Biomarkers of liver fibrosis: clinical translation of molecular pathogenesis or based on liverdependent malfunction tests. Clin Chim Acta 2007, 381:107-13.

33. Gobel T, Vorderwulbecke S, Hauck K, Fey H, Haussinger D, Erhardt A: New multi protein patterns differentiate liver fibrosis stages and hepatocellular carcinoma in chronic hepatitis $\mathrm{C}$ serum samples. World J Gastroenterol 2006, 12:7604-12.

34. Mas VR, Fisher RA, Archer KJ, Maluf DG: Proteomics and liver fibrosis: identifying markers of fibrogenesis. Expert Rev Proteomics 2009, 6:421-31.

35. Kuramitsu $Y$, Nakamura K: Current progress in proteomic study of hepatitis $C$ virus-related human hepatocellular carcinoma. Expert Rev Proteomics 2005, 2:589-601

36. Chen G, Gharib TG, Huang CC, Taylor JM, Misek DE, Kardia SL, Giordano TJ, lannettoni MD, Orringer MB, Hanash SM, Beer DG: Discordant protein and mRNA expression in lung adenocarcinomas. Mol Cell Proteomics 2002, 1:304-13.

37. Tian Q, Stepaniants SB, Mao M, Weng L, Feetham MC, Doyle MJ, Yi EC, Dai H, Thorsson V, Eng J, Goodlett D, Berger JP, Gunter B, Linseley PS, Stoughton RB, Aebersold R, Collins SJ, Hanlon WA, Hood LE: Integrated genomic and proteomic analyses of gene expression in Mammalian cells. Mol Cell Proteomics 2004, 3:960-9.

38. Pollack JR, Perou CM, Alizadeh AA, Eisen MB, Pergamenschikov A, Williams CF, Jeffrey SS, Botstein D, Brown PO: Genome-wide analysis of DNA copy-number changes using cDNA microarrays. Nat Genet 1999, 23:41-6.

39. Sellick GS, Longman C, Tolmie J, Newbury-Ecob R, Geenhalgh L, Hughes S, Whiteford M, Garrett C, Houlston RS: Genomewide linkage searches for Mendelian disease loci can be efficiently conducted using high-density SNP genotyping arrays. Nucleic Acids Res 2004, 32:e164.

40. Wang DG, Fan JB, Siao CJ, Berno A, Young P, Sapolsky R, Ghandour G, Perkins N, Winchester E, Spencer J, Kruglyak L, Stein L, Hsie L, Topaloglou T, Hubbell E, Robinson E, Mittmann M, Morris MS, Shen N, Kilburn D, Rioux J, Nusbaum C, Rozen S, Hudson TJ, Lipshutz R, Chee M, Lander ES: Largescale identification, mapping, and genotyping of single-nucleotide polymorphisms in the human genome. Science 1998, 280:1077-82.

41. Johnson JM, Castle J, Garrett-Engele P, Kan Z, Loerch PM, Armour CD, Santos R, Schadt EE, Stoughton R, Shoemaker DD: Genome-wide survey of human alternative pre-mRNA splicing with exon junction microarrays. Science 2003, 302:2141-4.

42. Yamamoto $M$, Wakatsuki $T$, Hada $A$, Ryo $A$ : Use of serial analysis of gene expression (SAGE) technology. J Immunol Methods 2001, 250:45-66.

43. Ruijter JM, Van Kampen AH, Baas F: Statistical evaluation of SAGE libraries: consequences for experimental design. Physiol Genomics 2002, 11:37-44.

44. Aebersold R, Mann M: Mass spectrometry-based proteomics. Nature 2003, 422:198-207.

45. Capelo JL, Carreira R, Diniz M, Fernandes L, Galesio M, Lodeiro C, Santos HM, Vale G: Overview on modern approaches to speed up protein identification workflows relying on enzymatic cleavage and mass spectrometry-based techniques. Anal Chim Acta 2009, 650:151-9.

46. Tonge R, Shaw J, Middleton B, Rowlinson R, Rayner S, Young J, Pognan F, Hawkins E, Currie I, Davison M: Validation and development of fluorescence two-dimensional differential gel electrophoresis proteomics technology. Proteomics 2001, 1:377-96. 
47. Unlu M, Morgan ME, Minden JS: Difference gel electrophoresis: a single gel method for detecting changes in protein extracts. Electrophoresis 1997, 18:2071-7.

48. Schwartz JC, Senko MW, Syka JE: A two-dimensional quadrupole ion trap mass spectrometer. J Am Soc Mass Spectrom 2002, 13:659-69.

49. Marshall $A G$, Hendrickson $C L$, Jackson GS: Fourier transform ion cyclotron resonance mass spectrometry: a primer. Mass Spectrom Rev 1998, 17:1-35.

50. Hardman M, Makarov AA: Interfacing the orbitrap mass analyzer to an electrospray ion source. Anal Chem 2003, 75:1699-705.

51. Hu Q, Noll RJ, Li H, Makarov A, Hardman M, Graham Cooks R: The Orbitrap: a new mass spectrometer. J Mass Spectrom 2005, 40:430-43.

52. Hutchens TA: Automaticity and reading in learning-disabled college students. Ann N Y Acad Sci 1993, 682:357-8.

53. Issaq HJ, Veenstra TD, Conrads TP, Felschow D: The SELDI-TOF MS approach to proteomics: protein profiling and biomarker identification. Biochem Biophys Res Commun 2002, 292:587-92.

54. De Bock M, de Seny D, Meuwis MA, Chapelle JP, Louis E, Malaise M, Merville MP, Fillet M: Challenges for biomarker discovery in body fluids using SELDI-TOF-MS. J Biomed Biotechnol 2010, 2010:906082.

55. Domon B, Aebersold R: Mass spectrometry and protein analysis. Science 2006, 312:212-7.

56. MacBeath $\mathrm{G}$, Schreiber SL: Printing proteins as microarrays for highthroughput function determination. Science 2000, 289:1760-3.

57. Low TY, Leow CK, Salto-Tellez M, Chung MC: A proteomic analysis of thioacetamide-induced hepatotoxicity and cirrhosis in rat livers. Proteomics 2004, 4:3960-74.

58. Henkel C, Roderfeld M, Weiskirchen R, Berres ML, Hillebrandt S, Lammert F, Meyer HE, Stuhler K, Graf J, Roeb E: Changes of the hepatic proteome in murine models for toxically induced fibrogenesis and sclerosing cholangitis. Proteomics 2006, 6:6538-48.

59. Shepard BD, Tuma DJ, Tuma PL: Chronic ethanol consumption induces global hepatic protein hyperacetylation. Alcohol Clin Exp Res 2010, 34:280-91

60. Andringa KK, King AL, Eccleston HB, Mantena SK, Landar A, Jhala NC, Dickinson DA, Squadrito GL, Bailey SM: Analysis of the liver mitochondrial proteome in response to ethanol and S-adenosylmethionine treatments: novel molecular targets of disease and hepatoprotection. Am J Physiol Gastrointest Liver Physiol 2010, 298:G732-45.

61. Kharbanda KK, Vigneswara V, McVicker BL, Newlaczyl AU, Bailey K, Tuma D, Ray DE, Carter WG: Proteomics reveal a concerted upregulation of methionine metabolic pathway enzymes, and downregulation of carbonic anhydrase-III, in betaine supplemented ethanol-fed rats. Biochem Biophys Res Commun 2009, 381:523-7.

62. Liu EH, Chen MF, Yeh TS, Ho YP, Wu RC, Chen TC, Jan YY, Pan TL: A useful model to audit liver resolution from cirrhosis in rats using functional proteomics. J Surg Res 2007, 138:214-23.

63. Kirpich IA, Gobejishvili LN, Bon Homme M, Waigel S, Cave M, Arteel G, Barve SS, McClain CJ, Deaciuc IV: Integrated hepatic transcriptome and proteome analysis of mice with high-fat diet-induced nonalcoholic fatty liver disease. J Nutr Biochem 2011, 22:38-45.

64. Zhang $X$, Yang J, Guo Y, Ye H, Yu C, Xu C, Xu L, Wu S, Sun W, Wei H, Gao X, Zhu Y, Qian X, Jiang Y, Li Y, He F: Functional proteomic analysis of nonalcoholic fatty liver disease in rat models: enoyl-coenzyme a hydratase down-regulation exacerbates hepatic steatosis. Hepatology 2010, 51:1190-9.

65. Kristensen DB, Kawada N, Imamura K, Miyamoto $Y$, Tateno C, Seki S, Kuroki T, Yoshizato K: Proteome analysis of rat hepatic stellate cells. Hepatology 2000, 32:268-77.

66. Kawada N, Kristensen DB, Asahina K, Nakatani K, Minamiyama Y, Seki S, Yoshizato K: Characterization of a stellate cell activation-associated protein (STAP) with peroxidase activity found in rat hepatic stellate cells. J Biol Chem 2001, 276:25318-23.

67. Deng $X$, Liang J, Lin ZX, Wu FS, Zhang YP, Zhang ZW: Natural taurine promotes apoptosis of human hepatic stellate cells in proteomics analysis. World J Gastroenterol 2010, 16:1916-23.

68. Yokoyama Y, Terai S, Ishikawa T, Aoyama K, Urata Y, Marumoto Y, Nishina H, Nakamura K, Okita K, Sakaida I: Proteomic analysis of serum marker proteins in recipient mice with liver cirrhosis after bone marrow cell transplantation. Proteomics 2006, 6:2564-70.

69. Shimada T, Nakanishi T, Toyama A, Yamauchi S, Kanzaki A, Fujiwake $H$, Sato TA, Ikegawa M: Potential implications for monitoring serum bile acid profiles in circulation with serum proteome for carbon tetrachlorideinduced liver injury/regeneration model in mice. J Proteome Res 2010, 9:4490-500.

70. Smyth R, Lane CS, Ashiq R, Turton JA, Clarke CJ, Dare TO, York MJ, Griffiths W, Munday MR: Proteomic investigation of urinary markers of carbon-tetrachloride-induced hepatic fibrosis in the Hanover Wistar rat Cell Biol Toxicol 2009, 25:499-512.

71. Walters KA, Katze MG: Using high-throughput genomics to study hepatitis C: what determines the outcome of infection? Antiviral Res 2009, 81:198-208.

72. Diamond DL, Jacobs JM, Paeper B, Proll SC, Gritsenko MA, Carithers RL Jr, Larson AM, Yeh MM, Camp DG, Smith RD, Katze MG: Proteomic profiling of human liver biopsies: hepatitis $C$ virus-induced fibrosis and mitochondrial dysfunction. Hepatology 2007, 46:649-57.

73. Molleken C, Sitek B, Henkel C, Poschmann G, Sipos B, Wiese S, Warscheid B, Broelsch C, Reiser M, Friedman SL, Tornoe I, Schlosser A, Kloppel G, Schmiegel W, Meyer HE, Holmskov U, Stuhler K: Detection of novel biomarkers of liver cirrhosis by proteomic analysis. Hepatology 2009, 49:1257-66.

74. White IR, Patel K, Symonds WT, Dev A, Griffin P, Tsokanas N, Skehel M, Liu C, Zekry A, Cutler P, Gattu M, Rockey DC, Berrey MM, McHutchison JG: Serum proteomic analysis focused on fibrosis in patients with hepatitis C virus infection. J Transl Med 2007, 5:33.

75. Chen L, Borozan I, Sun J, Guindi M, Fischer S, Feld J, Anand N, Heathcote J, Edwards AM, McGilvray ID: Cell-type specific gene expression signature in liver underlies response to interferon therapy in chronic hepatitis $C$ infection. Gastroenterology 2010, 138:1123-33, e1-3.

76. Gangadharan B, Antrobus R, Dwek RA, Zitzmann N: Novel serum biomarker candidates for liver fibrosis in hepatitis $C$ patients. Clin Chem 2007, 53:1792-9.

77. Suzman DL, McLaughlin M, Hu Z, Kleiner DE, Wood B, Lempicki RA, Mican JM, Suffredini A, Masur H, Polis MA, Kottilil S: Identification of novel markers for liver fibrosis in HIV/hepatitis $C$ virus coinfected individuals using genomics-based approach. AIDS 2008, 22:1433-9.

78. Yang L, Rudser KD, Higgins L, Rosen HR, Zaman A, Corless CL, David L, Gourley GR: Novel biomarker candidates to predict hepatic fibrosis in hepatitis c identified by serum proteomics. Dig Dis Sci 2011, 56:3305-15.

79. Corradi F, Piscaglia F, Flori S, D'Errico-Grigioni A, Vasuri F, Tame MR, Andreone P, Boni P, Gianstefani A, Bolondi L: Assessment of liver fibrosis in transplant recipients with recurrent HCV infection: usefulness of transient elastography. Dig Liver Dis 2009, 41:217-25.

80. Cheung KJ, Libbrecht L, Tilleman K, Deforce D, Colle I, Van Vlierberghe H: Galectin-3-binding protein: a serological and histological assessment in accordance with hepatitis C-related liver fibrosis. Eur J Gastroenterol Hepatol 2010, 22:1066-73.

81. Huang H, Shiffman ML, Friedman S, Venkatesh R, Bzowej N, Abar OT, Rowland CM, Catanese JJ, Leong DU, Sninsky JJ, Layden TJ, Wright TL White T, Cheung RC: A 7 gene signature identifies the risk of developing cirrhosis in patients with chronic hepatitis C. Hepatology 2007, 46:297-306.

82. Marcolongo M, Young B, Dal Pero F, Fattovich G, Peraro L, Guido M, Sebastiani G, Palu G, Alberti A: A seven-gene signature (cirrhosis risk score) predicts liver fibrosis progression in patients with initially mild chronic hepatitis C. Hepatology 2009, 50:1038-44.

83. Pradat $P$, Trepo E, Potthoff A, Bakshi R, Young B, Trepo C, Lagier R, Moreno C, Lemmers A, Gustot T, Degre D, Adler M, Wedemeyer H: The cirrhosis risk score predicts liver fibrosis progression in patients with initially mild chronic hepatitis C. Hepatology 2010, 51:356-7.

84. Narayan R, Gangadharan B, Hantz O, Antrobus R, Garcia A, Dwek RA, Zitzmann N: Proteomic analysis of HepaRG cells: a novel cell line that supports hepatitis B virus infection. J Proteome Res 2009, 8:118-22.

85. Dienstag JL, McHutchison JG: American Gastroenterological Association medical position statement on the management of hepatitis $C$. Gastroenterology 2006, 130:225-30

86. Asselah T, Bieche I, Narguet S, Sabbagh A, Laurendeau I, Ripault MP, Boyer N, Martinot-Peignoux M, Valla D, Vidaud M, Marcellin P: Liver gene expression signature to predict response to pegylated interferon plus ribavirin combination therapy in patients with chronic hepatitis C. Gut 2008, 57:516-24

87. Hayashida K, Daiba A, Sakai A, Tanaka T, Kaji K, Inaba N, Ando S, Kajiyama N, Terasaki H, Abe A, Ogasawara M, Kohara M, Harada M, Okanoue T, Ito S, 
Kaneko S: Pretreatment prediction of interferon-alfa efficacy in chronic hepatitis C patients. Clin Gastroenterol Hepatol 2005, 3:1253-9.

88. Feld JJ, Nanda S, Huang Y, Chen W, Cam M, Pusek SN, Schweigler LM, Theodore D, Zacks SL, Liang TJ, Fried MW: Hepatic gene expression during treatment with peginterferon and ribavirin: Identifying molecular pathways for treatment response. Hepatology 2007, 46:1548-63.

89. Suppiah V, Moldovan M, Ahlenstiel G, Berg T, Weltman M, Abate ML, Bassendine M, Spengler U, Dore GJ, Powell E, Riordan S, Sheridan D, Smedile A, Fragomeli V, Muller T, Bahlo M, Stewart GJ, Booth DR, George J: IL28B is associated with response to chronic hepatitis C interferon-alpha and ribavirin therapy. Nat Genet 2009, 41:1100-4.

90. Tanaka Y, Nishida N, Sugiyama M, Kurosaki M, Matsuura K, Sakamoto N, Nakagawa M, Korenaga M, Hino K, Hige S, Ito Y, Mita E, Tanaka E, Mochida S, Murawaki Y, Honda M, Sakai A, Hiasa Y, Nishiguchi S, Koike A, Sakaida I, Imamura M, Ito K, Yano K, Masaki N, Sugauchi F, Izumi N, Tokunaga K, Mizokami M: Genome-wide association of IL28B with response to pegylated interferon-alpha and ribavirin therapy for chronic hepatitis C. Nat Genet 2009, 41:1105-9.

91. Thompson AJ, Fellay J, Patel K, Tillmann HL, Naggie S, Ge D, Urban TJ, Shianna KV, Muir AJ, Fried MW, Afdhal NH, Goldstein DB, McHutchison JG: Variants in the ITPA gene protect against ribavirin-induced hemolytic anemia and decrease the need for ribavirin dose reduction. Gastroenterology 2010, 139:1181-9.

92. Sarasin-Filipowicz M, Oakeley EJ, Duong FH, Christen V, Terracciano L, Filipowicz W, Heim MH: Interferon signaling and treatment outcome in chronic hepatitis C. Proc Natl Acad Sci USA 2008, 105:7034-9.

93. Devitt EJ, Power KA, Lawless MW, Browne JA, Gaora PO, Gallagher WM, Crowe J: Early proteomic analysis may allow noninvasive identification of hepatitis $C$ response to treatment with pegylated interferon alpha- $2 \mathrm{~b}$ and ribavirin. Eur I Gastroenterol Hepatol 2011, 23:177-83.

94. Sun W, Zhong F, Zhi L, Zhou G, He F: Systematic -omics analysis of HBVassociated liver diseases. Cancer Lett 2009, 286:89-95.

95. Zhang L, Peng X, Zhang Z, Feng Y, Jia X, Shi Y, Yang H, Zhang X, Liu L, Yin L, Yuan Z: Subcellular proteome analysis unraveled annexin $A 2$ related to immune liver fibrosis. J Cell Biochem 2010, 110:219-28.

96. Lu Y, Liu J, Lin C, Wang H, Jiang Y, Wang J, Yang P, He F: Peroxiredoxin 2: a potential biomarker for early diagnosis of hepatitis $B$ virus related liver fibrosis identified by proteomic analysis of the plasma. BMC Gastroenterol 2010, 10:115.

97. Marrocco C, Rinalducci S, Mohamadkhani A, D'Amici GM, Zolla L: Plasma gelsolin protein: a candidate biomarker for hepatitis B-associated liver cirrhosis identified by proteomic approach. Blood Transfus 2010, 8(Suppl 3):s105-12.

98. Mohamadkhani A, Jazii FR, Sayehmiri K, Jafari-Nejad S, Montaser-Kouhsari L, Poustchi H, Montazeri G: Plasma myeloperoxidase activity and apolipoprotein A-1 expression in chronic hepatitis B patients. Arch Iran Med 2011, 14:254-8.

99. Poon TC, Hui AY, Chan HL, Ang IL, Chow SM, Wong N, Sung JJ: Prediction of liver fibrosis and cirrhosis in chronic hepatitis B infection by serum proteomic fingerprinting: a pilot study. Clin Chem 2005, 51:328-35.

100. Myers RP, Tainturier MH, Ratziu V, Piton A, Thibault V, Imbert-Bismut F, Messous D, Charlotte F, Di Martino V, Benhamou Y, Poynard T: Prediction of liver histological lesions with biochemical markers in patients with chronic hepatitis B. J Hepatol 2003, 39:222-30.

101. Wang J, Jiang D, Zhang H, Lv S, Rao H, Fei R, Wei L: Proteome responses to stable hepatitis $B$ virus transfection and following interferon alpha treatment in human liver cell line HepG2. Proteomics 2009, 9:1672-82.

102. Seth D, Gorrell MD, Cordoba S, McCaughan GW, Haber PS: Intrahepatic gene expression in human alcoholic hepatitis. J Hepatol 2006, 45:306-20.

103. Younossi ZM, Baranova A, Ziegler K, Del Giacco L, Schlauch K, Born TL, Elariny H, Gorreta F, VanMeter A, Younoszai A, Ong JP, Goodman Z, Chandhoke V: A genomic and proteomic study of the spectrum of nonalcoholic fatty liver disease. Hepatology 2005, 42:665-74.

104. Bell LN, Theodorakis JL, Vuppalanchi R, Saxena R, Bemis KG, Wang M, Chalasani N: Serum proteomics and biomarker discovery across the spectrum of nonalcoholic fatty liver disease. Hepatology 2010, 51:111-20.

105. Ulukaya E, Yilmaz Y, Moshkovskii S, Karpova M, Pyatnitskiy M, Atug O, Dolar E: Proteomic analysis of serum in patients with non-alcoholic steatohepatitis using matrix-assisted laser desorption ionization time-offlight mass spectrometry. Scand J Gastroenterol 2009, 44:1471-6.
106. Calvert VS, Collantes R, Elariny H, Afendy A, Baranova A, Mendoza M, Goodman Z, Liotta LA, Petricoin EF, Younossi ZM: A systems biology approach to the pathogenesis of obesity-related nonalcoholic fatty liver disease using reverse phase protein microarrays for multiplexed cell signaling analysis. Hepatology 2007, 46:166-72.

107. Wilfred de Alwis NM, Day CP: Genes and nonalcoholic fatty liver disease. Curr Diab Rep 2008, 8:156-63.

108. Gray J, Chattopadhyay D, Beale GS, Patman GL, Miele L, King BP, Stewart S, Hudson M, Day CP, Manas DM, Reeves HL: A proteomic strategy to identify novel serum biomarkers for liver cirrhosis and hepatocellular cancer in individuals with fatty liver disease. BMC Cancer 2009, 9:271.

109. Charlton M: Noninvasive indices of fibrosis in NAFLD: starting to think about a three-hit (at least) phenomenon. Am J Gastroenterol 2007, 102:409-11.

110. Juran BD, Lazaridis KN: Genetics and genomics of primary biliary cirrhosis. Clin Liver Dis 2008, 12:349-65, ix.

111. Shackel NA, McGuinness PH, Abbott CA, Gorrell MD, McCaughan GW: Identification of novel molecules and pathogenic pathways in primary biliary cirrhosis: CDNA array analysis of intrahepatic differential gene expression. Gut 2001, 49:565-76.

112. Li YZ, Hu CJ, Leng XM, Zhao GF, Li N, Xu Y: Promising diagnostic biomarkers for primary biliary cirrhosis identified with magnetic beads and MALDI-TOF-MS. Anat Rec (Hoboken) 2009, 292:455-60.

113. Tahiri F, Le Naour F, Huguet $S$, Lai-Kuen R, Samuel D, Johanet $C$, Saubamea B, Tricottet V, Duclos-Vallee JC, Ballot E: Identification of plasma membrane autoantigens in autoimmune hepatitis type 1 using a proteomics tool. Hepatology 2008, 47:937-48.

114. Song H, Sokolov M: Analysis of protein expression and compartmentalization in retinal neurons using serial tangential sectioning of the retina. J Proteome Res 2009, 8:346-51.

115. Bowlus CL, Seeley EH, Roder J, Grigorieva J, Roder H, Caprioli RM, Gershwin M: In situ mass spectrometry of autoimmune liver diseases. Cell Mol Immunol 2011, 8:237-42.

116. Villanueva A, Newell P, Chiang DY, Friedman SL, Llovet JM: Genomics and signaling pathways in hepatocellular carcinoma. Semin Liver Dis 2007, 27:55-76.

117. Makridakis M, Vlahou A: Secretome proteomics for discovery of cancer biomarkers. J Proteomics 2010, 73:2291-305.

118. Peng ZG, Fan B, Du NN, Wang YP, Gao LM, Li YH, Liu F, You XF, Han YX Zhao ZY, Cen S, Li JR, Song DQ, Jiang JD: Small molecular compounds that inhibit hepatitis $C$ virus replication through destabilizing heat shock cognate 70 messenger RNA. Hepatology 2010, 52:845-53.

doi:10.1186/1755-1536-5-1

Cite this article as: Hannivoort et al:: Genomics and proteomics in liver fibrosis and cirrhosis. Fibrogenesis \& Tissue Repair 2012 5:1.

\section{Submit your next manuscript to BioMed Central and take full advantage of:}

- Convenient online submission

- Thorough peer review

- No space constraints or color figure charges

- Immediate publication on acceptance

- Inclusion in PubMed, CAS, Scopus and Google Scholar

- Research which is freely available for redistribution

Submit your manuscript at www.biomedcentral.com/submit
C Biomed Central 